\title{
3D and Plasmonic Nanoparticle Decorated Catalytic System via Bio-inspired Polydopamine Coating: Cigar Filter Case Study
}

\author{
Biyo-esinlenmiş Polidopamin Kaplaması ile 3-Boyutlu ve \\ Nanoparçacıklarla Dekore Edilmiş Katalitik Sistem: Sigara Filtresi \\ Örnek İncelemesi
}

Research Article

\section{Mehmet Yılmaz',2}

'Ataturk University, Faculty of Engineering, Department of Chemical Engineering, Erzurum, Turkey.

${ }^{2}$ Ataturk University, East Anatolia High Technology Application and Research Center (DAYTAM), Erzurum, Turkey.

\section{A B S TRACT}

espite the significant progress, the well-controlled deposition of nanoparticles onto the support materials having 3D morphologies for the catalytic applications is still facing challenges such as the limited accessibility of reacting molecules to catalyst surface, uncontrolled aggregation of nanoparticles, high cost and highly complicated fabrication procedures. In this study, to overcome these challenges, a simple yet versatile alternative platform is proposed to control the gold nanoparticle (AuNP) size, surface coverage and morphology onto the 3D cigar filter surface via bio-inspired polydopamine (PDOP) coating. The effect of gold deposition time on AuNPs characteristics and their catalytic activity in the model reaction were investigated in detail. It is found that both AuNPs characteristics and catalytic activity can be controlled by changing deposition time. The deposition of AuNPs via functional groups of PDOP such as amine, catechol, and imine provided total conversion of 4-nitrophenol to 4-aminophenol within an hour.

\section{Key Words}

Gold nanoparticles, polydopamine, catalytic conversion.

\section{Ö z}

\begin{abstract}
Kayda değer ilerlemelere rağmen, nanopartiküllerin 3-boyutlu morfolojiye sahip destek malzemeleri üzeI rine kontrollü olarak katalitik uygulamalar için biriktirilmeleri, reaktif maddenin katalizör yüzeyine sınırlı erişimi, nanopartiküllerin kontrolsüz olarak çökmesi, yüksek fiyat ve karmaşık üretim işlemleri gibi birçok zorluklarla hala karşı karşıyadır. Bu çalışmada, bu zorlukları aşmak amacıyla biyoesinlenmiş polidopamin (PDOP) kaplaması ile 3-boyutlu sigara filtresi üzerinde altın nanopartiküllerin (AuNP) büyüklük, yüzey kaplanması ve morfolojisi kontrol edilerek basit fakat kullanışlı alternatif bir platform önerilmiştir. Altın biriktirme süresinin AuNP karakteristiği ve model tepkimedeki katalitik aktiviteye olan etkisi ayrıntılı şekilde araştırılmıştır. Hem AuNP özelliklerinin hem de katalitik aktivitenin biriktirme süresi ile kontrol edilebileceği belirlenmiştir. Amin, katekol, imin gibi PDOP fonksiyonel grupları ile AuNP biriktirilmesi, 4-nitrofenolün 4-aminofenole tamamen dönüşümünü bir saat içinde sağlamıştır.
\end{abstract}

\section{Anahtar Kelimeler}

Altın nanoparçacıklar, polidopamin, katalitik dönüşüm.

Article History: Received: Apr 13, 2018; Revised: May 17, 2018; Accepted: Sep 24, 2018; Available Online: Nov 13, 2018.

DOI: $10.15671 /$ HJBC.2018.259

Correspondence to: M. Yılmaz, Ataturk University, Faculty of Engineering, Department of Chemical Engineering, Erzurum, Turkey. 


\section{INTRODUCTION}

$\mathrm{M}$ etallic nanoparticles with their unique properties find applications in many research fields such as photoelectronics [1,2], catalysis [3], magnetism [4,5] and sensing $[6,7]$. Several properties of metallic nanoparticles can be manipulated by controlling their size, shape, and morphology [8]. Wet-chemical procedures have been widely used for synthesis of nanoparticles because of their advantages including simplicity, high growth rate and throughput. However, the stabilization and dispersion of metallic nanoparticles in solution is still a challenging task that limits their usage especially in catalytic applications. Surface modification with different polymers, complex ligands, and surfactants are frequently employed to stabilize metal catalytic nanoparticles $[9,10]$. However, in most cases, these stabilizers hinder the accessibility of reacting molecules to metal particles and alter the reaction mechanism or decrease the reaction rate [11]. Therefore, it is clear that novel techniques must be developed to investigate the catalytic activity of nanoparticles.

Some new strategies have been proposed for the fabrication of 3D, low cost and effective supported-metal catalyst systems [12]. For this, polymeric, inorganic or carbon based support materials have been employed in different fabrication procedures [13-17]. In line with this, recently, we tested the catalytic activity of vertically aligned and well-ordered silicon nanowire (SiNW) arrays as an ideal supported-metal catalyst system [18]. SiNW arrays were prepared through metal-assisted chemical etching and a thin layer of polydopamine (PDOP) was created onto the arrays via oxidative polymerization of dopamine molecules. The thin layer of PDOP can be virtually coated on almost all solid supports with high stability. Besides, due to the functional groups of PDOP such as amine, catechol, and imine, metallic nanoparticles can also be deposited onto any supports without using any reducing agent or metallic seed particles [19]. Despite of its high catalytic activity, the proposed system has some major bottlenecks including highly toxic materials to prepare SiNWs, high number of preparation steps and high cost of materials. In this study, to overcome these problems, we propose the cigar filter as low-cost, disposable and biobased supported-metal catalyst system. For this, similar strategies was employed to fabricate nanoparticle decorated catalytic system. Firstly, a thin layer of PDOP was created onto cigar filter. Afterwards, gold nanoparticles (AuNPs) were deposited onto the cigar filter simply by immersion into the chloroauric acid solution. The size and morphology of AuNPs as well as their surface coverage were controlled by manipulating deposition time. The catalytic performances nanoparticle decorated cigar filter was tested via model reduction reaction of 4-nitrophenol (4-NP) to 4-aminophenol (4-AP) in the presence of $\mathrm{NaBH}_{4}$.

\section{MATERIALS and METHODS \\ Fabrication of Gold Nanoparticle Decorated PDOP Coated Cigar Filters}

Prior to PDOP film deposition, cigar filter were cleaned by immersing in DI water for $10 \mathrm{~min}$. Afterwards, the cigar filters were dried with $\mathrm{N}_{2}$ gas flow. For the deposition of PDOP layer, firstly, the cigar filters were immersed into a dopamine solution (dopamine hydrochloride (Sigma H8502), $2 \mathrm{mg} \mathrm{mL}^{-1}$ in $10 \mathrm{mM}$ Tris buffer, $\mathrm{pH}$ 8.5) at room temperature for $3 \mathrm{~h}$. Then, the filters were rinsed with DI water and dried with $\mathrm{N}_{2}$ flow. To grow the gold nanoparticles along the surface, filters were treated with chloroauric acid solution $(0.1 \mathrm{mg} \mathrm{mL}$ 1) for different deposition times (3-24h). Finally, gold decorated cigar filters were washed with excess DI water and dried with $\mathrm{N}_{2}$ flow.

\section{Characterization}

The UV-Vis absorption spectra to monitor the catalytic activity tests were obtained by using a Shimadzu 2600 UV-Vis-near-IR recording spectrophotometer. Scanning electron microscopy (SEM) images were recorded with a JEOL JSM-6060LV and FEI Nova 200 Nanolab SEM/FIB. The size distributions, densities and surface coverage of nanoparticles were calculated via free ImageJ software.

\section{Catalytic Activity Tests}

The catalytic activity of the PDOP coated cigar filters with/without gold nanoparticles was tested for the conversion of 4-nitrophenol (4-NP) into 4-aminophenol (4-AP). For this, cigar filters was immersed into $9 \mathrm{~mL}$ of solution containing $1 \times 10^{-4} \mathrm{M}$ of $4-\mathrm{NP}$ and $0.033 \mathrm{M}$ of $\mathrm{NaBH}_{4}$. The catalytic conversion was monitored by UV-visible 
spectroscopy through decrease in absorption band of $\mathrm{p}-\mathrm{NA}$ centered at $381 \mathrm{~nm}$ and increase in absorption band of 4-AP centered at $304 \mathrm{~nm}$.

\section{RESULTS and DISCUSSION}

The procedure that has been applied in this study was summarized in Figure 1. In the first step the as-cleaned cigar filter was immersed into dopamine solution to create thin conformal layer of PDOP for $3 \mathrm{~h}$. Our earlier reports depicted that the thickness of PDOP layer can be tuned by manipulating oxidative polymerization time of dopamine and the $3 \mathrm{~h}$ of exposure time is quite reasonable to deposit PDOP layer in desired thickness $(\sim 10 \mathrm{~nm})[18,20,21]$. The oxidation of dopamine and the emergence of PDOP was detected by naked eye on the cigar filter. After PDOP deposition, AuNPs were decorated all over the fibers of the cigar filter by immersing into the chloroauric acid solution. The reduction of gold ions onto the filter resulted in vivid red color.

SEM technique was employed to analyze the characteristics of the deposited AuNPs. Before the PDOP and AuNPs deposition, plain cigar filter with microfibers with average diameter of $10 \mu \mathrm{m}$ was detected (Figure 2a,b). After conformal PDOP deposition, no remarkable morphological change was detected from the cigar filter microfibers (Figure 2c,d). However, after the immersion into the gold salt solution, the color of PDOP coated cigar filter turned from grey to red. The intensity of the red color was getting darker and darker over time indicating both increase in AuNPs number density and size onto microfibers. This observation clearly depicts that a thin layer of PDOP with abundant catechol, amine and imine functional groups can serve as a reducing agent for the decoration

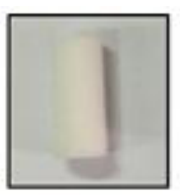

\section{Cigar filter}

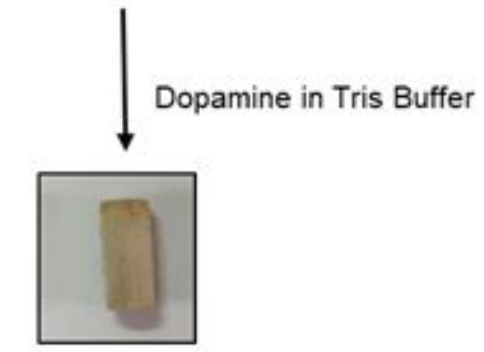

PDOP@Cigar filter

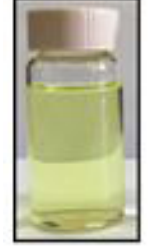<smiles>Nc1ccc([N+](=O)[O-])cc1</smiles>

AuNP decorated cigar filter

$\mathrm{NaBH}_{4}$
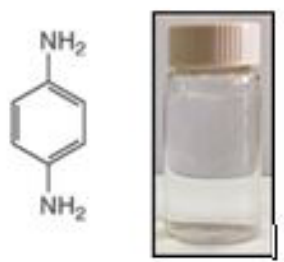

Figure 1. The experimental procedures that summarize the deposition of AuNPs and catalytic conversion. 


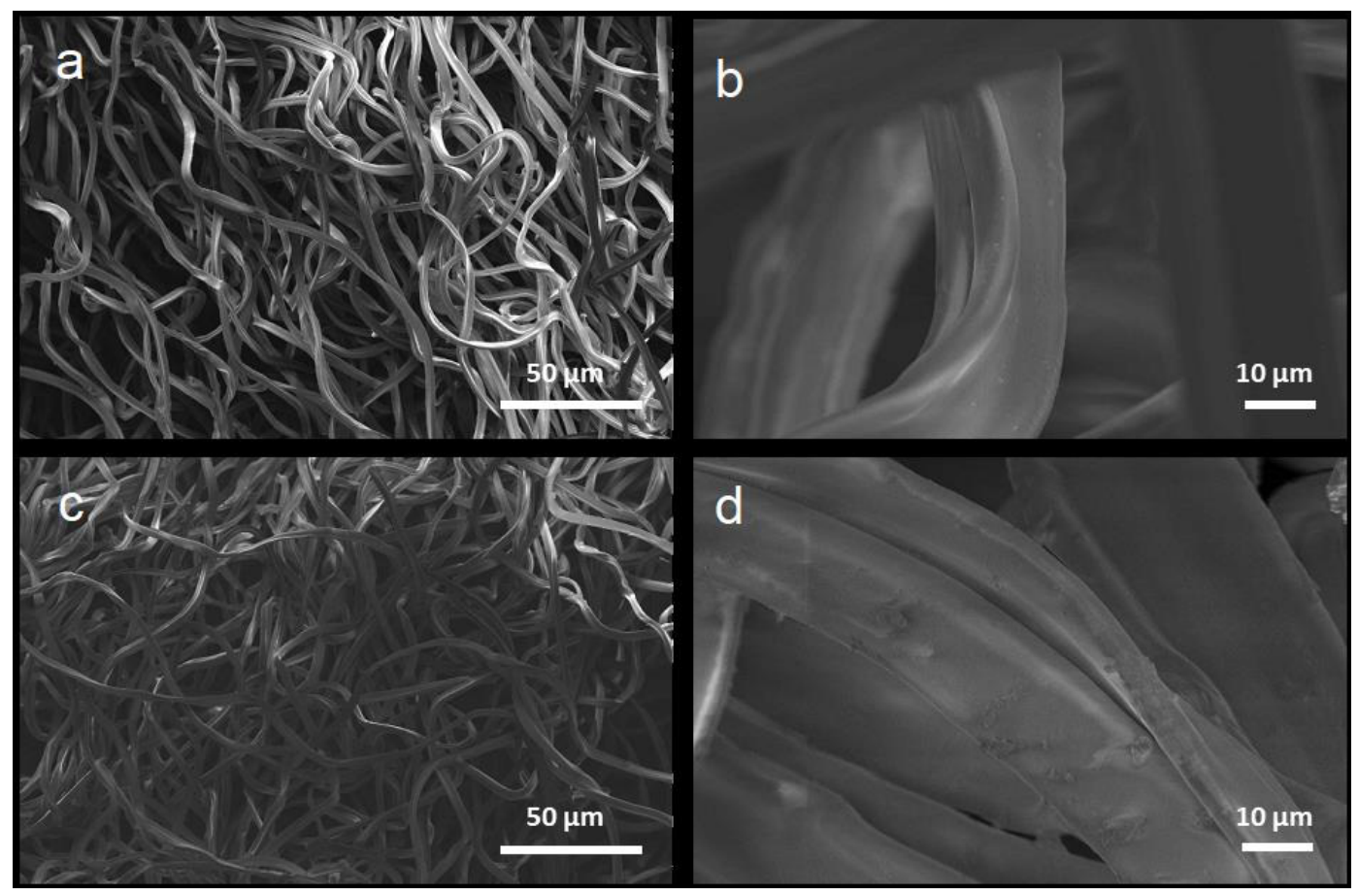

Figure 2. SEM images of plain cigar filter ( $a$ and b) and PDOP coated cigar filter (c and d) at different magnifications.

of metallic nanoparticles. To prove the PDOP effect, the same procedure was applied to plain microfibers (noncoated with PDOP). For this case, no color change and no nanoparticle deposition was observed via SEM images (data not shown here). To determine the effect of AuNPs numbers density and size on the catalytic performance of the relevant fibers, cigar filter was kept in the gold salt solution for different deposition times (3$24 \mathrm{~h})$. The final morphology of AuNPs decorated cigar filter fibers was summarized in Figure 3. For the all cases, it seems that the nanoparticles were deposited all over the fiber surface. However, it is clear that the deposition time is the dominant effect that determine not only nanoparticle density but also its final morphology and size. For the case of low deposition time ( $3 \mathrm{~h}$ ), AuNPs with very uniform size were observed onto fiber surface (Figure $3 a, b$ ). The statistical analysis via free ImageJ software resulted in nanoparticles with average size of $60 \mathrm{~nm}$ and almost unimodal size distribution (see inset of Figure 3a). When the deposition time was increased from 3 to $12 h$, both surface coverage (number density of nanoparticles) and average nanoparticle size were increased, accordingly (Figure $3 c, d$ ). As a result of the higher deposition of gold ions as AuNPs, minority of nanoparticles started to merge and create some nanoparticle aggregation with higher nanoparticle size and multimodal size distribution (see inset of Figure 3c). The average nanoparticle size was calculated as approximately $90 \mathrm{~nm}$. Further increase in deposition time (24 h) led to higher deposition gold ions as well as higher number of aggregated nanoparticles (Figure $3 e, f$ ). For this case, nanoparticles have multimodal size distribution with average size of $110 \mathrm{~nm}$ (see inset of Figure 3e). From SEM analysis, we can conclude that AuNPs can be decorated all over surface of the cigar filter and their main characteristics such as nanoparticle size and morphology could be manipulated through deposition time.

\section{Plasmonic metallic nanoparticle decorated 3D nano/micro-structures may provide} remarkable catalytic performances for the some chemical conversions. In this study, the proposed AuNPs decorated cigar filter was tested in catalytic conversion of 4-NP into 4-AP. The catalytic conversion for this transformation is thermodynamically possible in the presence of aqueous $\mathrm{NaBH}_{4}$. However, the large potential difference between the borohydride donor $\left(\mathrm{BH}_{4}^{-}\right)$ and acceptor (4-NP) molecules leads to the kinetic barrier and limits the degree of this reaction $[20,22]$. In the presence of metal nanoparticles, electron relay from donor to acceptor molecules is easily actualized. The catalytic reduction of 4-NP can be effectively monitored via UV-vis absorption 


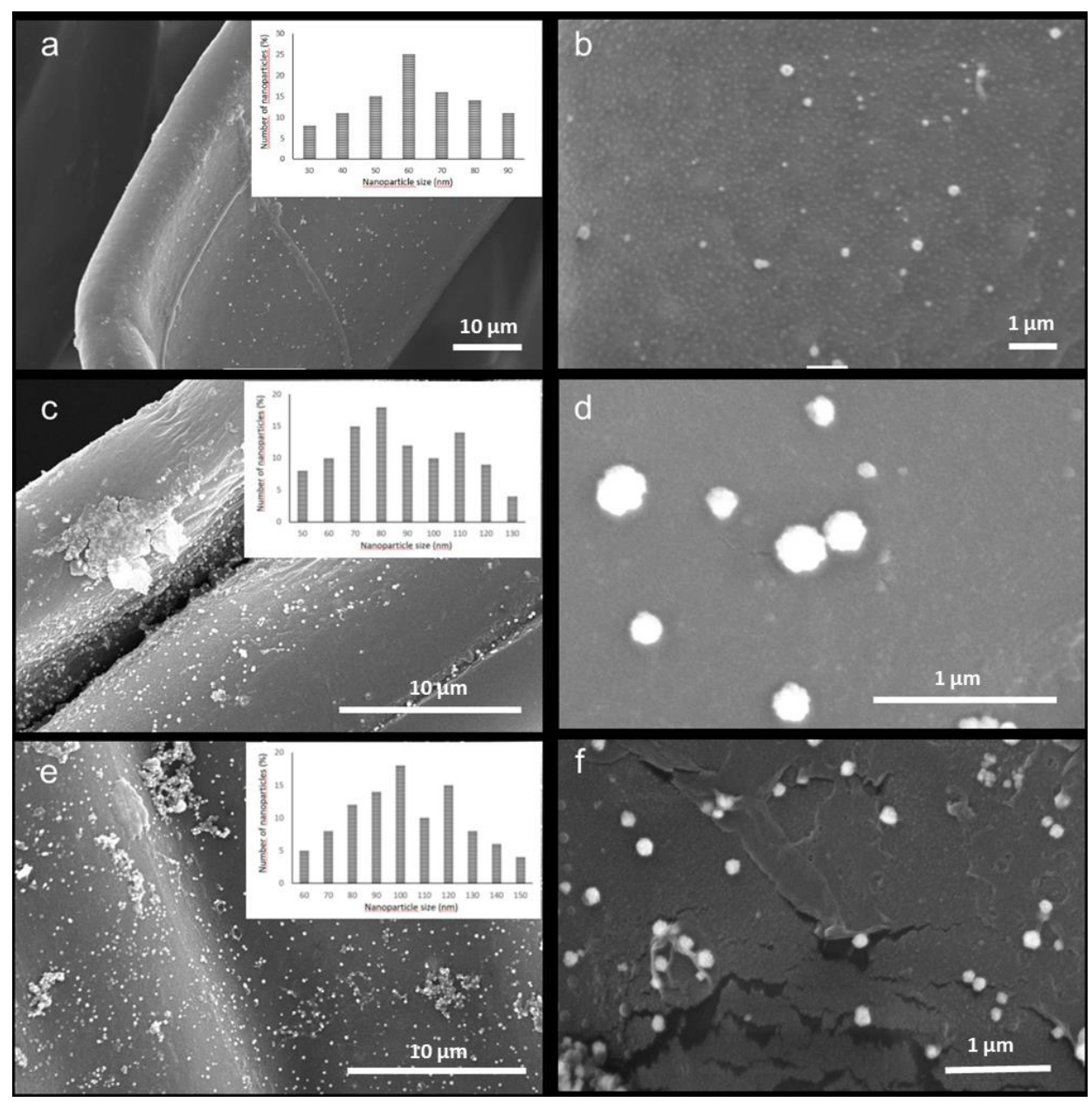

Figure 3. SEM images of gold nanoparticle decorated PDOP coated cigar filter for different gold reduction times: $3 \mathrm{~h}$ ( $\mathrm{a}$ and b), $12 \mathrm{~h}$ ( $\mathrm{c}$ and d) and $24 \mathrm{~h}$ (e and f). Insets show the nanoparticle size distribution for the corresponding gold deposition times.

spectra. Firstly, we employed PDOP coated cigar filters without AuNP deposition. For this case, a small decrease in the absorption peak at $\lambda_{\max }=381$ $\mathrm{nm}$ was detected with no emergence of 4 -AP (Figure 4a). This small change was attributed to favorable physical adsorption of 4-NP molecules onto the PDOP coated cigar filter. However, when AuNPs decorated cigar filters were employed, we noticed that the absorption at $381 \mathrm{~nm}$ gradually decreased and a new peak appeared at $304 \mathrm{~nm}$, indicating the formation of 4-AP. Also, an obvious color change from yellow to colorless could be observed by nakedeye in the solution due to the catalytic conversion (Figure 1). For the case of $3 \mathrm{~h}$ gold deposited cigar filters (Figure 4a), almost complete conversion was achieved within 60 min. However, $12 \mathrm{~h}$ gold deposited filters led to a relatively higher catalytic activity with a significantly lower total conversion time of $20 \mathrm{~min}$. Prolonging deposition time to 24 $\mathrm{h}$ resulted in lower catalytic activity as depicted in
Figure 4c. Considering pseudo-first-order reaction kinetics as shown in Figure 5 , the rate constants are found to be $0.02,0.035$ and $0.032 \mathrm{~min}^{-1}$ for 3 , 12 and $24 \mathrm{~h}$ gold deposited cigar filters, respectively. When compared to that of 3 and $24 \mathrm{~h}$ deposited filters, the remarkably higher catalytic activity of 12 $\mathrm{h}$ gold deposited cigar filters can be attributed to its favorably higher surface coverage of nanoparticles almost without any aggregation of nanoparticles. In other words, the lower surface coverage of nanoparticles and the higher extent of nanoparticle aggregation resulted in lower catalytic activity for the case of gold deposition times of 3 and 24 $h$, respectively (see Figure 3 ). It must be noted that these catalytic performances with these rate constants are comparable to those of some recently reported $\mathrm{Au}$-based catalysts in the literature $[23,24]$. However, large-scale and facile fabrication of the current proposed AuNP decorated cigar filters may pave the way for the development of recoverable, 


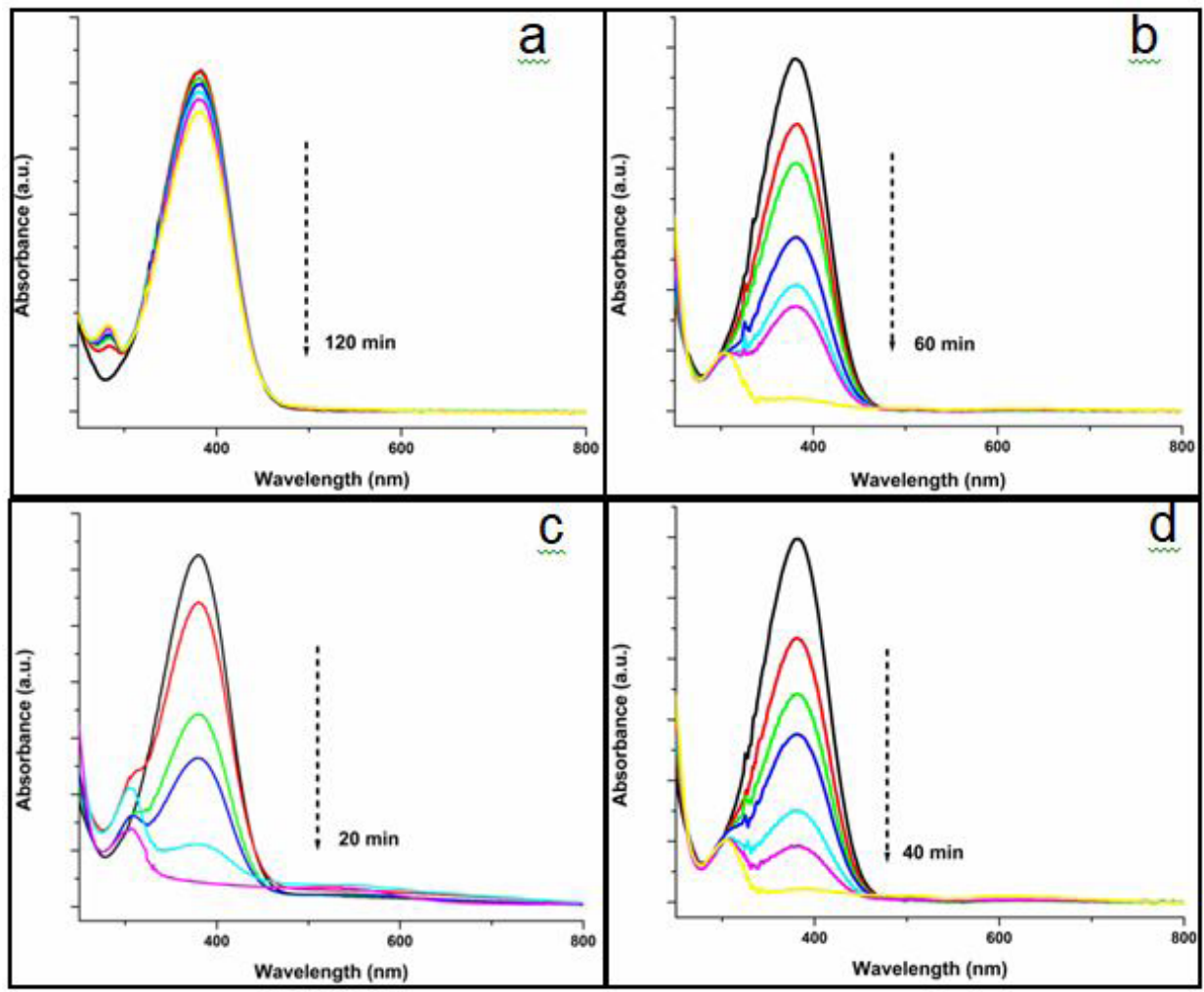

Figure 4. Time evolution of the UV-vis spectra, showing the conversion of 4-NP to 4-AP for PDOP coated cigar filters without (a) and with gold nanoparticle decorated at different reduction times (b; $3 \mathrm{~h}, \mathrm{c} ; 12 \mathrm{~h}$ and, d; $24 \mathrm{~h}$ ) of gold ions.

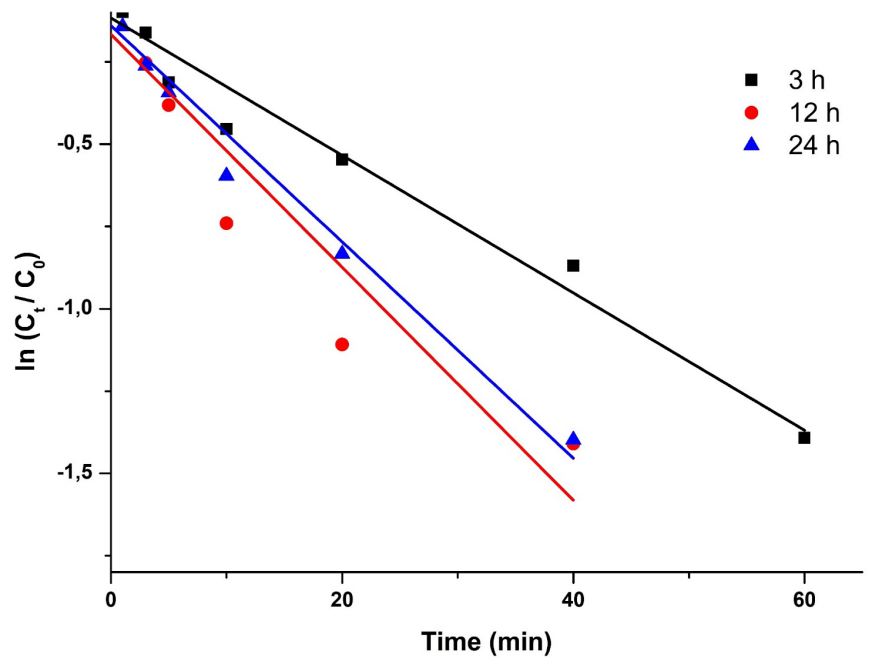

Figure 5. Kinetic trace of concentration for the different reduction times of gold onto the cigar filter for the comparison.

low-cost, and bio-inspired catalysis platforms [2,2426].

\section{CONCLUSION}

In summary, I have reported a simple, versatile, low-cost, and efficient 3D supported-metal catalytic system via deposition of gold nanoparticles onto the cigar filter through a thin layer of PDOP. It was shown that the size and surface coverage of gold nanoparticle can be easily manipulated by changing deposition time. PDOP, due to the its vast functional groups including catechol, amine, and imine, led to in-situ formation of metallic nanoparticles in a controlled manner without use of any reductive agent or metallic seed agent. Also, 3D morphology of 
the proposed catalytic system could increase the accessibility of reacting molecules to metal particles and boost the reaction rate. I strongly believe that the proposed method not only allows for control over nanoparticle size and density but also serves as a promising catalytic system compared to traditional ones.

\section{References}

1. P. Sudeep, B.I. Ipe, K.G. Thomas, M. George, S. Barazzouk, S. Hotchandani, P.V. Kamat, Fullerenefunctionalized gold nanoparticles. A self-assembled photoactive antenna-metal nanocore assembly, Nano Lett., 2 (2002) 29-35.

2. K. Kuroda, T. Ishida, M. Haruta, Reduction of 4-nitrophenol to 4-aminophenol over $\mathrm{Au}$ nanoparticles deposited on PMMA, J. Mol. Cat. A: Chem., 298 (2009) 7-11.

3. B. Gates, Supported metal clusters: synthesis, structure, and catalysis, Chem. Rev., 95 (1995) 511522.

4. X. Li, S. Takahashi, K. Watanabe, Y. Kikuchi, M. Koishi, Hybridization and Characteristics of $\mathrm{Fe}$ and $\mathrm{Fe}-\mathrm{Co}$ Nanoparticles with Polymer Particles, Nano Lett., 1 (2001) 475-480.

5. X. Sun, A. Gutierrez, M.J. Yacaman, X. Dong, S. Jin, Investigations on magnetic properties and structure for carbon encapsulated nanoparticles of $\mathrm{Fe}, \mathrm{Co}, \mathrm{Ni}$, Mater. Sci. Eng.: A, 286 (2000) 157-160.

6. Y. Kim, R.C. Johnson, J.T. Hupp, Gold nanoparticlebased sensing of "spectroscopically silent" heavy metal ions, Nano Lett., 1 (2001) 165-167.

7. M. Yilmaz, E. Senlik, E. Biskin, M.S. Yavuz, U. Tamer, G. Demirel, Combining 3-D plasmonic gold nanorod arrays with colloidal nanoparticles as a versatile concept for reliable, sensitive, and selective molecular detection by SERS, Phys. Chem. Chem. Phys., 16 (2014) 5563-5570.

8. A.P. Alivisatos, Semiconductor clusters, nanocrystals, and quantum dots, Science, 271 (1996) 933-937.

9. T.S. Ahmadi, Z.L. Wang, T.C. Green, A. Henglein, M.A. El-Sayed, Shape-controlled synthesis of colloidal platinum nanoparticles, Science, 272 (1996) 19241925.

10. D.M. Hercules, A. Proctor, M. Houalla, Quantitative analysis of mixed oxidation states in supported catalysts, Acc. Chem. Res., 27 (1994) 387-393.

11. Z.-J. Jiang, C.-Y. Liu, L.-W. Sun, Catalytic properties of silver nanoparticles supported on silica spheres, The J. Phys. Chem. B, 109 (2005) 1730-1735.

12. R.J. White, R. Luque, V.L. Budarin, J.H. Clark, D.J. Macquarrie, Supported metal nanoparticles on porous materials. Methods and applications, Chem. Soc. Rev., 38 (2009) 481-494.
13. M. Benaglia, A. Puglisi, F. Cozzi, Polymer-supported organic catalysts, Chem. Rev., 103 (2003) 3401-3430.

14. N.E. Leadbeater, M. Marco, Preparation of polymersupported ligands and metal complexes for use in catalysis, Chem. Rev., 102 (2002) 3217-3274.

15. B.F. Machado, P. Serp, Graphene-based materials for catalysis, Cat. Sci. \& Tech., 2 (2012) 54-75.

16. C.E. Song, S.G. Lee, Supported chiral catalysts on inorganic materials, Chem. Rev., 102 (2002) 34953524.

17. A. Taguchi, F. Schüth, Ordered mesoporous materials in catalysis, Micro. and Meso. Mater., 77 (2005) 1-45.

18. G. Bakirci, M. Yilmaz, E. Babur, D. Ozden, G. Demirel, Understanding the effect of polydopamine coating on catalytic reduction reactions, Cat. Comm., 91 (2017) 48-52.

19. Y. Liu, K. Ai, L. Lu, Polydopamine and its derivative materials: synthesis and promising applications in energy, environmental, and biomedical fields, Chem. Rev., 114 (2014) 5057-5115.

20. M. Yilmaz, G. Bakirci, H. Erdogan, U. Tamer, G. Demirel, The fabrication of plasmonic nanoparticle-containing multilayer films via a bio-inspired polydopamine coating, RSC Adv., 6 (2016) 12638-12641.

21. M.S. Akin, M. Yilmaz, E. Babur, B. Ozdemir, H. Erdogan, U. Tamer, G. Demirel, Large area uniform deposition of silver nanoparticles through bio-inspired polydopamine coating on silicon nanowire arrays for practical SERS applications, J. Mater. Chem. B, 2 (2014) 4894-4900.

22. A. Gangula, R. Podila, L. Karanam, C. Janardhana, A.M. Rao, Catalytic reduction of 4-nitrophenol using biogenic gold and silver nanoparticles derived from Breynia rhamnoides, Langmuir, 27 (2011) 1526815274.

23. S. Panigrahi, S. Basu, S. Praharaj, S. Pande, S. Jana, A. Pal, S.K. Ghosh, T. Pal, Synthesis and size-selective catalysis by supported gold nanoparticles: study on heterogeneous and homogeneous catalytic process, J. Phys. Chem. C, 111 (2007) 4596-4605.

24. B. Adhikari, A. Biswas, A. Banerjee, Graphene oxide-based hydrogels to make metal nanoparticlecontaining reduced graphene oxide-based functional hybrid hydrogels, ACS Appl. Mater. \& Inter., 4 (2012) 5472-5482.

25. M. Yılmaz, M. Erkartal, M. Ozdemir, U. Sen, H. Usta, G. Demirel, Three-Dimensional Au-Coated Electrosprayed Nanostructured BODIPY Films on Aluminum Foil as Surface-Enhanced Raman Scattering Platforms and Their Catalytic Applications, ACS Appl. Mater. \& Inter., 9 (2017) 18199-18206.

26. J. Lee, J.C. Park, H. Song, A Nanoreactor Framework of a Au@ SiO2 Yolk/Shell Structure for Catalytic Reduction of p Nitrophenol, Adv. Mater., 20 (2008) 1523-1528. 
